\title{
HELICHRYSUM CYMOSUM (L.) D.DON (ASTERACEAE): MEDICINAL USES, CHEMISTRY, AND BIOLOGICAL ACTIVITIES
}

\author{
ALFRED MAROYI* \\ Department of Botany, Medicinal Plants and Economic Development Research Centre, University of Fort Hare, Private Bag X1314, \\ Alice 5700, South Africa. Email: amaroyi@ufh.ac.za
}

Received: 26 April 2019, Revised and Accepted: 24 May 2019

\begin{abstract}
Helichrysum cymosum is a valuable and well-known medicinal plant in tropical Africa. The current study critically reviewed the medicinal uses, phytochemistry and biological activities of $H$. cymosum. Information on medicinal uses, phytochemistry and biological activities of $H$. cymosum, was collected from multiple internet sources which included Scopus, Google Scholar, Elsevier, Science Direct, Web of Science, PubMed, SciFinder, and BMC. Additional information was gathered from pre-electronic sources such as journal articles, scientific reports, theses, books, and book chapters obtained from the University library. This study showed that H. cymosum is traditionally used as a purgative, ritual incense, and magical purposes and as herbal medicine for colds, cough, fever, headache, and wounds. Ethnopharmacological research revealed that $H$. cymosum extracts and compounds isolated from the species have antibacterial, antioxidant, antifungal, antiviral, anti-HIV, anti-inflammatory, antimalarial, and cytotoxicity activities. This research showed that H. cymosum is an integral part of indigenous pharmacopeia in tropical Africa, but there is lack of correlation between medicinal uses and existing pharmacological properties of the species. Therefore, future research should focus on evaluating the chemical and pharmacological properties of H. cymosum extracts and compounds isolated from the species.
\end{abstract}

Keywords: Asteraceae, Ethnopharmacology, Helichrysum cymosum, Herbal medicine, Indigenous pharmacopeia, Tropical Africa.

(C) 2019 The Authors. Published by Innovare Academic Sciences Pvt Ltd. This is an open access article under the CC BY license (http://creativecommons. org/licenses/by/4. 0/) DOI: http://dx.doi.org/10.22159/ajpcr.2019.v12i7.33771

\section{INTRODUCTION}

Helichrysum cymosum (L.) D.Don is a member of the Asteraceae or Compositae family, commonly referred to as aster, daisy, or sunflower family. The family Asteraceae is one of the largest families of flowering plants, which is cosmopolitan except for Antarctica region [1-3]. The family consists of over 1600 genera and 23,000 species which have been recorded in grassland, wooded grassland, montane vegetation, and tropical forests [1]. Research by Jeschke et al. [4] showed that the family Asteraceae has at least 420 known medicinal species and these include Arnica montana L. [5-11], Artemisia annua L. [12-19], Calendula officinalis L. [20-25], Chamaemelum nobile (L.) All. [26-30], Inula helenium L. [31-36], and Matricaria recutita L. [37-43]. Another important source of herbal medicines among Asteraceae taxa is the genus Helichrysum Mill. [44-60]. According to Lourens et al. [61] and Pljevljakušić et al. [62], the genus Helichrysum is characterized by acylphloroglucinols, humulone derivatives, flavonoids, chalcones, phenolic acids, phthalides, sterols, coumarins, pyrones, diterpenes, sesquiterpenes, and polyacetylenes. The genus Helichrysum is characterized by several biological activities such as antimicrobial, antiinflammatory, antioxidant, cholagogue, choleretic, hepatoprotective, detoxifying, protease-inhibiting, and antiallergic properties [61-63]. H. cymosum (L.) D.Don, Helichrysum aureonitens Sch. Bip., Helichrysum nudifolium (L.) Less., Helichrysum odoratissimum (L.) Sweet, Helicltrysum pedunculatum Hilliard and B.L. Burtt., and Helichrysum petiolare Hilliard and B.L.Burtt. are among the species widely used as herbal medicines in South Africa [64]. The genus name "Helichrysum" is derived from the Greek words "helios" which means "sun" and "chrysos" which means "gold," in reference to the "golden flowers" which are characteristic of the genus [62]. The specific name "cymosum" is a Latin word which means "with cymes" in reference to the flat-topped clusters of flower heads, as the flowers of the species occur in clusters in which the flowers open from the center outward [65]. The leaves, stems, and twigs of $H$. cymosum are sold as herbal medicines in the informal herbal medicine markets in the Gauteng and the Western Cape provinces in South Africa [66-68]. Therefore, the current study is aimed at providing a critical appraisal of the existing ethnomedicinal value, phytochemistry and biological activities of $H$. cymosum, as well as exploring the potential of the species as herbal medicine in tropical Africa.

\section{BOTANICAL DESCRIPTION OF H. CYMOSUM}

In South Africa, H. cymosum is known as gold carpet or yellow-tipped strawflower in English, goute tapyt in Afrikaans, and impepho in isiXhosa or Zulu [65]. H. cymosum is divided into two subspecies, H. cymosum subsp. cymosum and $H$. cymosum subsp. calvum Hilliard $[65,69]$. These two subspecies are differentiated on the basis that the head of subsp. cymosum has 6-20 flowers, fimbrils are more than twice as long as the ovary, and the pappus is copious $[65,70]$. While the head of subsp. calvum has 4-7 flowers, fimbrils are about as long as the ovary and the pappus is wanting $[65,70]$. In South Africa, subsp. calvum is shorter, ranging in height from 15 to $55 \mathrm{~cm}$ and has been recorded at an altitude ranging from 1200 to $3170 \mathrm{~m}$ above sea level [69]. The subsp. cymosum is taller than subsp. calvum, with height ranging from 10 to $180 \mathrm{~cm}$ and has been recorded at an altitude ranging from 5 to $2010 \mathrm{~m}$ above sea level [69]. However, most ethnobotanical and ethnopharmacological literature does not separate $H$. cymosum into specific subspecies but rather to H. cymosum sensu lato, and this is the approach that has been adopted in this study. There are four synonyms associated with H. cymosum and these include Gnaphalium cymosum L., G. serratum L., G. tricostatum Sieber ex DC., Helichrysum infaustum J.M. Wood and M.S. Evans var. discolor Moeser, and Lepiscline cymosa Cass [69,70].

H. cymosum is a well-branched spreading, perennial dwarf shrub with thin grayish-white woolly branches densely covered with leaves and becoming pedunculoid upward. The leaves are variable in shape and size, becoming smaller and more distant upward. The leaves are elliptic-oblong or linear-oblong in shape, the apex is acute, sometimes acuminate, mucronate, slightly narrowed, and clasping at the base $[65,70]$. The leaf margins are flat or subrevolute, upper surface covered in thin silvery gray and paper-like hairs, while the lower surface has white-woolly hairs. The flower heads are disciform, 
sometimes discoid, crowded in terminal corymbs, cylindric, glossy, and bright canary-yellow in color [71].

\section{MEDICINAL USES OF H. CYMOSUM}

The aerial parts, flowers, leaves, roots, twigs, and whole plant parts of H. cymosum are used for various traditional and medicinal applications (Table 1). H. cymosum is mainly used as a purgative, ritual incense, and magical purposes (chase away evil spirits and rain making) and as herbal medicine for colds, cough, fever, headache, and wounds (Table 1 and Figure 1). Other minor medicinal applications include blocked nose, boost immunity, cardiovascular problems, diarrhea, dizziness, eye problems, flatulence, improve appetite, influenza, insect repellent, insomnia, kidney problems, laxative, menstrual pain, pertussis, pulmonary problems, skin infections, urinary problems, varicose veins, vomiting, and weak bones [72-81]

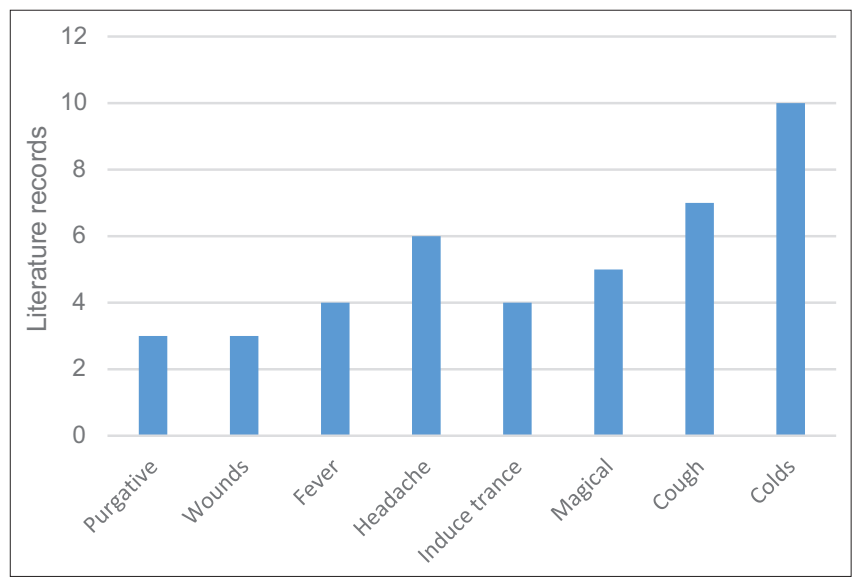

Figure 1: Traditional and medicinal applications of Helichrysum cymosum

\section{PHYTOCHEMICAL AND NUTRITIONAL COMPOSITION OF H. CYMOSUM}

Very little attention has been paid to the macro- and microelements of $H$. cymosum. One report done by Street et al. [90] partly studied this subject and reported values of the nutritional composition of leaves, roots, and stems of H. cymosum (Table 2). Bohlmann et al. [91], Jakupovic et al. [92], and van Vuuren et al. [89] identified helihumulone, helichromanochalcone, and 5-hydroxy-8-methoxy7-prenyloxyflavanone from leaves and roots of $H$. cymosum. The composition of essential oils appears to vary with the geographical origin of the specimens as shown in Table 3. The major compounds that have been identified from the species include $\alpha$-pinene $(0.8 \%-12.4 \%), \quad \Delta$-3-carene $\quad(6.8 \%-16.1 \%), \quad \beta$-caryophyllene $(8.5 \%-17.8 \%), \quad 1,8$-cineole $(1.0 \%-20.4 \%)$, trans-caryophyllene $(27.0 \%)$, and $(\mathrm{Z})-\beta$-ocimene $(<0.01 \%-50.4 \%)$ [85,89,93-97]. Future research should focus on evaluating the biological activities of the isolated compounds.

\section{BIOLOGICAL ACTIVITIES}

The following biological activities have been reported from $H$. cymosum crude extracts and compounds isolated from the species: Antibacterial [72,74,85,89,94], antioxidant [95], antifungal [89,94,95,98], antiviral [72], anti-HIV [99,100], antiinflammatory [74], antimalarial [89], cytotoxicity [99,100], and toxicity [89] activities.

\section{Antibacterial activities}

Sindambiwe et al. [72] evaluated antibacterial activities of $80 \%$ ethanol whole plant extracts of $H$. cymosum using the liquid dilution method against Escherichia coli, Klebsiella pneumoniae, Proteus vulgaris, Pseudomonas aeruginosa, Salmonella paratyphi, Bacillus cereus, Mycobacterium fortuitum, Staphylococcus aureus, and Streptococcus pyogenes. The extract was active against $S$. pyogenes with minimum inhibitory concentration (MIC) value of $5 \mathrm{mg} / \mathrm{ml}$ [72]. Stafford

Table 1: Medicinal uses of Helichrysum cymosum

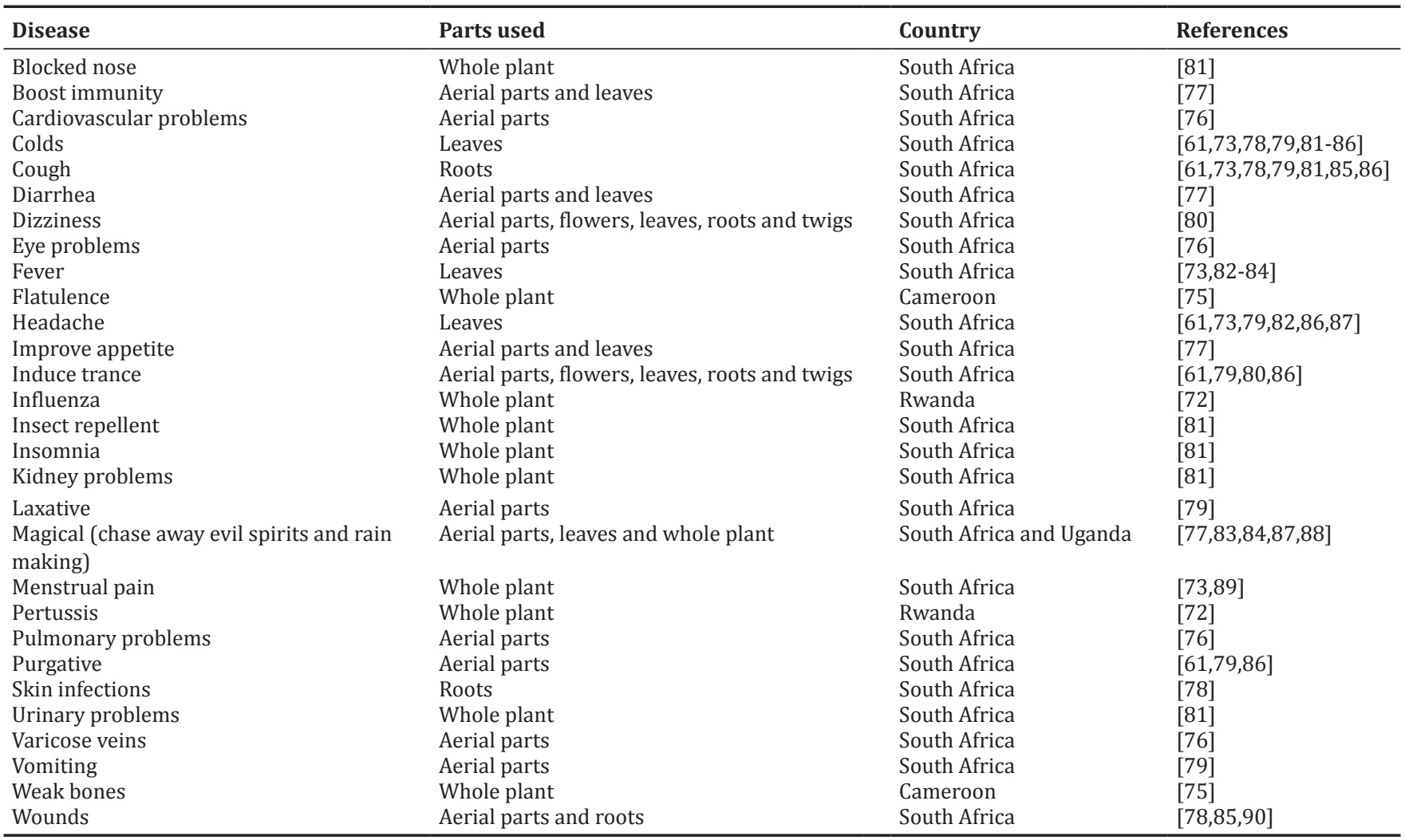


Table 2: Nutritional composition of leaves, roots, and stems of Helichrysum cymosum based on studies done by Street et al. ${ }^{[90]}$

\begin{tabular}{ll}
\hline Nutritional composition $(\mathbf{m g} / \mathbf{k g})$ & Values \\
\hline Arsenic & 0.8 \\
Boron & 21.2 \\
Cadmium & 0.4 \\
Cobalt & 0.9 \\
Copper & 0.8 \\
Iron & 1087.8 \\
Lead & 2.0 \\
Manganese & 759.6 \\
Molybdenum & 0.5 \\
Nickel & 4.0 \\
Zinc & 42.9 \\
\hline
\end{tabular}

et al. [74] evaluated the antibacterial activities of ethanol extracts of whole plant parts of $H$. cymosum against Bacillus subtilis, S. aureus, E. coli, and K. pneumonia using the micro plate method. The extract exhibited activities with MIC values ranging from 0.8 to $1.6 \mathrm{mg} / \mathrm{ml}$ [74]. Van Vuuren et al. [89] and Van Vuuren [94] evaluated the antibacterial activities of acetone extracts of aerial parts of $H$. cymosum, essential oil and compound helihumulone isolated from the species against Enterococcus faecalis, B. cereus, B. subtilis, S. aureus, P. aeruginosa, Yersinia enterocolitica, and $E$. coli using disc diffusion and microdilution techniques with ciprofloxacin as a positive control. The extract exhibited activities against E. faecalis, B. cereus, B. subtilis, and $S$. aureus with zone of inhibition ranging from 3.7 to $8.0 \mathrm{~mm}$ which was comparable to $3.0 \mathrm{~mm}$ to $11 \mathrm{~mm}$ exhibited by the positive control. The extract, essential oil and compound helihumulone exhibited activities with MIC values ranging from 0.02 to $8.0 \mathrm{mg} / \mathrm{ml}[89,94]$. Reddy [85] evaluated antibacterial activities of acetone and methanol extracts of aerial parts of $H$. cymosum as well as essential oils isolated from the species against E. coli, Yersinia enterocolitica, Klebsiella pneumoniae, S. aureus, and B. cereus using disc diffusion assay with ciprofloxacin $(0.01 \mathrm{mg} / \mathrm{ml})$ as a positive control. The acetone and methanol extracts exhibited activities against $S$. aureus and B. cereus with zone of inhibition of 7 and $5 \mathrm{~mm}$, respectively, and MIC value of $<0.25 \mathrm{mg} / \mathrm{ml}$ exhibited against both pathogens. The positive control exhibited zone of inhibition of $6 \mathrm{~mm}$ and MIC value of $0.0003 \mathrm{mg} / \mathrm{ml}$ [85].

\section{Antioxidant activities}

François et al. [95] evaluated the antioxidant activities of essential oil isolated from the leaves of $H$. cymosum using 2,2-diphenyl-1picrylhydrazyl (DPPH) free radical scavenging assay with butylated hydroxytoluene as a positive control. The extract exhibited activities with $\mathrm{SC}_{50}$ (concentration of sample required to scavenge $50 \%$ of DPPH radicals) value of $6.3 \mathrm{~g} / \mathrm{l}$ which was less than the value of the positive control which exhibited value of $7.0 \mathrm{mg} / \mathrm{l}$ [95].

\section{Antifungal activities}

Van Vuuren et al. [89] and Van Vuuren [94] evaluated the antifungal activities of acetone extract of aerial parts of H. cymosum, essential oil and compound helihumulone isolated from the species against Cryptococcus neoformans and Candida albicans using microdilution technique with amphotericin B as a positive control. The extract, essential oil and compound helihumulone exhibited activities with MIC values ranging from 0.03 to $4.0 \mathrm{mg} / \mathrm{ml}[89,94]$. François et al. [95] evaluated the antifungal activities of essential oil isolated from the leaves of $H$. cymosum against Penicillium oxalicum using microdilution technique with amphotericin B as a positive control. The extract showed activities with $54.7 \%$ inhibition starting from 2.5 to $5 \mathrm{mg} / \mathrm{ml}$ [95]. Runyoro et al. [98] evaluated the antifungal activities of the essential oils isolated from $H$. cymosum against $C$. albicans using the bioautography agar overlay method with amphotericin B $(0.01 \mu \mathrm{g})$ as a positive control. The extract showed activities with zone of inhibition ranging from 6 to $8.5 \mathrm{~mm}$ while the positive control exhibited zone of inhibition of $14.2 \mathrm{~mm}$ [98].

\section{Antiviral activities}

Sindambiwe et al. [72] evaluated antiviral activities of aqueous and $80 \%$ ethanol whole plant part extracts of $H$. cymosum using the method of $50 \%$ end point titration technique (50\% EPTT) assay against herpes simplex virus Type 1, measles virus strain Edmonston A, Semliki Forest virus A7 (SF A7), and vesicular stomatitis virus T2 (VSV T2). The extract exhibited virucidal activities against VSV T2 and SF A7 [72].

\section{Anti-HIV activities}

Heyman [99] evaluated anti-HIV activities of methanol:water and chloroform extracts of aerial parts of $H$. cymosum subsp. Cymosum on Vero African green monkey kidney cells using the cytopathic effect (CPE) inhibition assay with acyclovir $(0.75 \mu \mathrm{g} / \mathrm{ml})$ as a positive control. The methanol:water extract showed slight toxicity with CPE of $400.0 \mu \mathrm{g} / \mathrm{ml}$ in comparison to $0.8 \mu \mathrm{g} / \mathrm{ml}$ exhibited by the positive control [99]. Heyman [79] and Heyman et al. [100] evaluated anti-HIV activities of dichloromethane and methanol/water extracts of aerial parts of $H$. cymosum subsp. Cymosum and H. cymosum subsp. Clavum using the DeCIPhR method. The extracts exhibited activities with median lethal concentration value ranging from 10.0 to $21.0 \mu \mathrm{g} / \mathrm{mL}[79,100]$.

\section{Anti-inflammatory activities}

Stafford et al. [74] evaluated the anti-inflammatory activities of aqueous and ethanol extracts of whole plant parts of $H$. cymosum using the cyclooxygenase (COX-1) inhibition assay. The COX-1 inhibition exhibited by aqueous and ethanol extract was $52.0 \%$ and $100.0 \%$, respectively [74].

\section{Antimalarial activities}

Van Vuuren et al. [89] evaluated the antimalarial activities of acetone extract of aerial parts of $H$. cymosum, essential oil and compound helihumulone isolated from the species using the $\left[\mathrm{G}^{-}{ }^{3} \mathrm{H}\right]$ hypoxanthine incorporation assay using Plasmodium falciparum as the test organism with chloroquine and quinine as positive controls. The extract, essential oil and compound helihumulone showed activities, exhibiting half maximal inhibitory concentration ( IC $_{50}$ ) values of $60.8 \mu \mathrm{g} / \mathrm{ml}, 1.3 \mu \mathrm{g} / \mathrm{ml}$ and $14.9 \mu \mathrm{g} / \mathrm{ml}$, respectively. The positive controls exhibited $\mathrm{IC}_{50}$ values ranging from 0.09 to $0.1 \mu \mathrm{g} / \mathrm{ml}$ [89].

\section{Cytotoxicity activities}

Heyman [99] evaluated cytotoxicity activities of chloroform and methanol:water extracts of aerial parts of $H$. cymosum subsp. cymosum on Vero African green monkey kidney cells using the XTT (sodium 3'-[1-(phenyl amino-carbonyl)-3,4-tetrazolium]-bis-[4-methoxy6-nitro] benzene sulfonic acid hydrate) method with zearalenone as a positive control. The chloroform and methanol:water extracts exhibited $\mathrm{IC}_{50}$ values of $36.5 \mu \mathrm{g} / \mathrm{ml}$ and $59.7 \mu \mathrm{g} / \mathrm{ml}$, respectively, which were higher than $1.3 \mu \mathrm{g} / \mathrm{ml}$ exhibited by the positive control [99]. Heyman [79] and Heyman et al. [100] evaluated anti-HIV activities of dichloromethane and methanol/water extracts of aerial parts of $H$. cymosum subsp. cymosum and $H$. cymosum subsp. Clavum using the DeCIPhR method. The extracts exhibited activities with median lethal dose value of $>50.0 \mu \mathrm{g} / \mathrm{mL}[79,100]$.

\section{Toxicity activities}

Van Vuuren et al. [89] evaluated the toxicity activities of acetone extract of aerial parts of $H$. cymosum, essential oil and compound helihumulone isolated from the species against transformed human kidney epithelial cells using a colorimetric tetrazolium-based 3-[4,5-dimethylthiazol2-yl]-2,5-diphenyltetrazolium bromide cellular viability assay. The extract, essential oil and compound helihumulone showed activities, exhibiting $\mathrm{IC}_{50}$ values of $172.0 \mu \mathrm{g} / \mathrm{ml}, 17.5 \mu \mathrm{g} / \mathrm{ml}$, and $57.1 \mu \mathrm{g} / \mathrm{ml}$, respectively [89].

\section{CONCLUSION}

In this review, the medicinal uses, phytochemistry, biological and toxicity activities of different extracts, and compounds of $H$. cymosum have been summarized. The diverse medicinal uses of $H$. cymosum and the preliminary phytochemical and ethnopharmacological 
Table 3: Phytochemical composition of Helichrysum cymosum

\begin{tabular}{|c|c|c|c|}
\hline Phytochemical composition (\%) & Values & Plant parts & References \\
\hline cis-Alloocimene & 0.4 & Aerial parts & {$[85,89,94]$} \\
\hline$\alpha$-Amorphene & $<0.01-3.7$ & Aerial parts, flowers and leaves & {$[93,97]$} \\
\hline Aromadendrene & $1.5-3.6$ & Aerial parts and leaves & {$[85,89,94,95]$} \\
\hline$(+)$-Aromadendrene & 1.4 & Aerial parts & [93] \\
\hline Alloaromadendrene & $<0.01-1.3$ & Flowers and leaves & [97] \\
\hline Aromadendrene epoxide & 0.08 & Aerial parts & [93] \\
\hline Benzaldehyde & $0.1-0.3$ & Aerial parts & {$[85,89,94]$} \\
\hline Benzylacetone & 0.3 & Aerial parts & {$[85,89,94]$} \\
\hline Bicyclogermacrene & 0.9 & Aerial parts & [93] \\
\hline Borneol & $<0.1-1.8$ & Aerial parts and leaves & {$[85,89,93-95]$} \\
\hline Bornylene & 2.7 & Leaves & [95] \\
\hline$\beta$-Bourbonene & $0.2-0.6$ & Aerial parts & {$[85,89,93,94]$} \\
\hline trans-Cadina-1 (6),4-diene & 0.1 & Flowers and leaves & {$[97]$} \\
\hline$\alpha$-Cadinol & $0.1-0.7$ & Aerial parts, flowers and leaves & {$[85,89,93-95,97]$} \\
\hline epi- $\alpha$-Cadinol & $0.1-0.3$ & Flowers and leaves & [97] \\
\hline$\delta$-Cadinol & 0.3 & Aerial parts & [93] \\
\hline$\alpha$-Cadinene & $<0.01$ & Flowers and leaves & [97] \\
\hline$\gamma$-Cadinene & 2.0 & Aerial parts & [93] \\
\hline$\delta$-Cadinene & $0.3-1.6$ & Aerial parts, flowers and leaves & {$[85,93,97]$} \\
\hline trans- $\gamma$-Cadinene & $0.1-0.3$ & Flowers and leaves & [97] \\
\hline$\alpha$-Calacorene & $<0.01-0.1$ & Aerial parts, flowers and leaves & {$[85,89,94,97]$} \\
\hline$\beta$-Calacorene & 0.4 & Aerial parts & [93] \\
\hline Calamenene & 0.6 & Aerial parts & {$[85]$} \\
\hline cis-Calamenene & 0.6 & Aerial parts & {$[89,94]$} \\
\hline Camphene & $0.1-7.4$ & Aerial parts, flowers and leaves & {$[85,89,93-95,97]$} \\
\hline Camphor & $<0.01-0.04$ & Aerial parts, flowers and leaves & {$[93,97]$} \\
\hline$\Delta$-3-Carene & $6.8-16.1$ & Aerial parts and leaves & {$[93,95]$} \\
\hline Carvacrol & 1.6 & Flowers & [97] \\
\hline trans-(+)-Carveol & $0.09-0.2$ & Aerial parts & {$[85,89,93,94]$} \\
\hline Caryophylla-4 (14),8 (15)-dien-5-ol & $0.1-0.2$ & Flowers and leaves & [97] \\
\hline Caryophylladienol I & $<0.01$ & Aerial parts & {$[85,89,94]$} \\
\hline Caryophylladienol II & 0.4 & Aerial parts & {$[85,89,94]$} \\
\hline Caryophyllenol I & 0.2 & Aerial parts & {$[85,89,94]$} \\
\hline Caryophyllenol II & 0.1 & Aerial parts & {$[85,89,94]$} \\
\hline Caryophyllene alcohol(\%) & $<0.01-1.1$ & Aerial parts, flowers and leaves & {$[93,97]$} \\
\hline$\alpha$-Caryophyllene alcohol & 1.2 & Aerial parts & [93] \\
\hline$\beta$-Caryophyllene alcohol & 0.4 & Aerial parts & {$[85,89,93]$} \\
\hline Caryophyllene oxide & $1.1-7.7$ & Aerial parts, flowers and leaves & {$[85,89,93-95,97]$} \\
\hline trans-Caryophyllene & 27.0 & Aerial parts & [93] \\
\hline$\beta$-Caryophyllene(\%) & $8.5-17.8$ & Aerial parts, flowers and leaves & {$[85,89,94-97]$} \\
\hline 1,8-Cineole & $1.0-20.4$ & Aerial parts, flowers and leaves & {$[85,89,94,95,97]$} \\
\hline Clovenol & 0.1 & Aerial parts & {$[85,89,94]$} \\
\hline$\alpha$-Copaene & $0.3-1.8$ & Aerial parts, flowers and leaves & {$[85,89,93-95,97]$} \\
\hline$\beta$-Copaene & $<0.01-0.1$ & Flowers and leaves & [97] \\
\hline 1-epi-Cubenol & $0.1-0.2$ & Flowers and leaves & [97] \\
\hline Cyclosativene & $<0.01-0.2$ & Flowers and leaves & [97] \\
\hline o-Cymene & $0.4-0.7$ & Flowers and leaves & [97] \\
\hline p-Cymen-8-ol & $0.1-0.2$ & Aerial parts & {$[85,89,93,94]$} \\
\hline p-Cymene & $0.6-7.6$ & Aerial parts and leaves & {$[85,89,93-95]$} \\
\hline Decanal & 1.4 & Flowers & [97] \\
\hline 1,10-Di-epi-cubenol & $0.1-0.2$ & Flowers and leaves & [97] \\
\hline Dodecanal & 0.3 & Flowers & [97] \\
\hline$\beta$-Elemene & 0.8 & Leaves & [95] \\
\hline$\delta$-Elemene & 1.9 & Leaves & [95] \\
\hline Epiglobulol & 0.3 & Aerial parts & {$[85,89,94]$} \\
\hline$\alpha$-Eudesmol & 1.3 & Leaves & [95] \\
\hline$\beta$-Eudesmol & 2.7 & Leaves & [95] \\
\hline E, e- $\alpha$-Farnesene & 1.6 & Aerial parts & [93] \\
\hline$\alpha$-Fenchene & $0.1-6.3$ & Aerial parts & {$[85,89,93,94]$} \\
\hline Fenchyl alcohol & 0.7 & Aerial parts & {$[85,89,94]$} \\
\hline$\beta$-Fenchyl alcohol & 0.9 & Aerial parts & [93] \\
\hline endo-Fenchol & 0.2 & Aerial parts & [93] \\
\hline Furfuryl alcohol & 0.2 & Aerial parts & [93] \\
\hline Germacrene B & 2.3 & Leaves & [95] \\
\hline Germacrene D & 0.6 & Leaves & [95] \\
\hline Globulol & $0.6-1.5$ & Aerial parts and leaves & {$[85,89,94,95]$} \\
\hline$\alpha$-Guaiene & 1.7 & Flowers & [97] \\
\hline$\delta$-Guaiene & 1.1 & Aerial parts & {$[85,89,94]$} \\
\hline Guaiol & $0.1-0.2$ & Flowers and leaves & [97] \\
\hline$\alpha$-Gurjunene & 0.1 & Aerial parts & {$[85,89,94]$} \\
\hline
\end{tabular}


Table 3: (Continued)

\begin{tabular}{|c|c|c|c|}
\hline Phytochemical composition (\%) & Values & Plant parts & References \\
\hline 2-Heptanol & 0.1 & Aerial parts & {$[85,89,94]$} \\
\hline 1-Hexanol & $<0.01$ & Aerial parts & {$[85,89,94]$} \\
\hline (Z)-3-Hexen-1-ol & 0.1 & Aerial parts & {$[85,89,94]$} \\
\hline (3E)-3-Hexen-1-yl acetate & 1.6 & Flowers & [97] \\
\hline (Z)-3-Hexen-1-yl 3-methylbutyrate & 1.2 & Flowers & [97] \\
\hline Humulene epoxide II & 0.2 & Aerial parts & {$[85,89,94]$} \\
\hline Humulene oxide & 0.9 & Leaves & [95] \\
\hline$\alpha$-Humulene & $1.2-8.7$ & Aerial parts, flowers and leaves & {$[85,89,94,95]$} \\
\hline Humulene epoxide II & $0.9-2.3$ & Flowers and leaves & [97] \\
\hline Isoborneol & 0.2 & Flowers & {$[97]$} \\
\hline Isobornyl acetate & 4.3 & Flowers & [97] \\
\hline endo-Isocamphane & 0.06 & Aerial parts & [93] \\
\hline Isocaryophyllene oxide & 0.1 & Aerial parts & {$[85,89,94]$} \\
\hline iso-Italicene & 0.1 & Flowers & [97] \\
\hline Limonen-4-ol & 0.2 & Aerial parts & {$[85,89,94]$} \\
\hline Limonene & $0.5-7.2$ & Aerial parts, flowers and leaves & {$[85,89,93,95,97]$} \\
\hline Linalool & $<0.01-1.6$ & Aerial parts and leaves & {$[85,89,93-95]$} \\
\hline trans-Linalool oxide & 0.1 & Aerial parts & [93] \\
\hline Longiborneol ( = Juniperol) & 0.2 & Flowers and leaves & {$[97]$} \\
\hline cis-p-Mentha-1 (7),8-dien-2-ol & $<0.01$ & Aerial parts & {$[85,89,94]$} \\
\hline cis-p-Menth-3-en-1,2-diol & 0.1 & Aerial parts & {$[85,89,94]$} \\
\hline Methyl hexyl bourgene & 7.2 & Leaves & [95] \\
\hline$\alpha$-Muurolene & $0.1-1.5$ & Aerial parts, flowers and leaves & {$[85,93,97]$} \\
\hline$\gamma$-Muurolene & $0.3-0.6$ & Flowers and leaves & [97] \\
\hline t-Muurolol & 1.2 & Aerial parts & {$[89,94]$} \\
\hline Myrcene & $0.4-1.2$ & Aerial parts, flowers and leaves & {$[85,89,93,94,97]$} \\
\hline (E)-Myroxide(\%) & 0.3 & Flowers and leaves & [97] \\
\hline (Z)-Myroxide(\%) & $<0.01-0.3$ & Flowers and leaves & [97] \\
\hline Myrtenol & 0.6 & Aerial parts & {$[85,89,94]$} \\
\hline Nerol & 0.4 & Aerial parts & [93] \\
\hline Neryl acetate & 0.7 & Aerial parts & [93] \\
\hline Nonanal(\%) & $<0.01-4.0$ & Flowers and leaves & {$[97]$} \\
\hline 2-Nonanol & $0.1-1.2$ & Aerial parts & {$[85,89,94]$} \\
\hline 2-Nonanone & 0.4 & Aerial parts & {$[85,89,94]$} \\
\hline Phellandral & 0.09 & Aerial parts & [93] \\
\hline$\alpha$-Phellandrene epoxide & 0.2 & Aerial parts & [93] \\
\hline 2-Phenylethyl acetate & $<0.01$ & Aerial parts & {$[85,89,94]$} \\
\hline cis- $\beta$-Ocimene & 0.3 & Aerial parts & [93] \\
\hline trans- $\beta$-Ocimene & 0.2 & Aerial parts & [93] \\
\hline (E)- $\beta$-Ocimene & $<0.01-8.0$ & Aerial parts, flowers and leaves & {$[85,89,94,95,97]$} \\
\hline$(Z)-\beta$-Ocimene & $<0.01-50.4$ & Aerial parts, flowers and leaves & {$[85,89,94,95,97]$} \\
\hline allo-Ocimene & 6.4 & Flowers & [97] \\
\hline neo-allo-Ocimene & 0.6 & Flowers & [97] \\
\hline 2-Octanol & 0.5 & Aerial parts & {$[85,89,94]$} \\
\hline 1-Octen-3-ol & $0.3-0.8$ & Aerial parts & {$[85,89,93,94]$} \\
\hline Octyl acetate & 1.6 & Leaves & [95] \\
\hline Perilla aldehyde & 0.1 & Flowers and leaves & [97] \\
\hline$\alpha$-Pinene & $0.8-12.4$ & Aerial parts, flowers and leaves & {$[85,89,93-97]$} \\
\hline$\beta$-Pinene & $0.5-3.7$ & Aerial parts, flowers and leaves & {$[85,89,93,95,97]$} \\
\hline$\alpha$-Pinene oxide & $0.3-0.5$ & Flowers and leaves & [97] \\
\hline Pinocarvone & 0.1 & Aerial parts & {$[85,89,94]$} \\
\hline trans-Pinocarveol & 0.6 & Aerial parts & {$[85,89,94]$} \\
\hline Rosifoliol & 0.2 & Aerial parts & {$[85,89,94]$} \\
\hline Sabinene & $0.2-1.0$ & Aerial parts and flowers & {$[85,89,94,97]$} \\
\hline cis-Sabinene hydrate & 0.4 & Flowers and leaves & [97] \\
\hline Safranal & 0.04 & Aerial parts & [93] \\
\hline Selina-5,11-diene & 0.3 & Aerial parts & {$[85,89,94]$} \\
\hline$\alpha$-Selinene & 2.3 & Leaves & [95] \\
\hline$\gamma$-Selinene & 1.2 & Leaves & [95] \\
\hline$\beta$-Selinene & $0.7-5.7$ & Flowers and leaves & {$[95,97]$} \\
\hline Spathulenol & 0.9 & Leaves & [95] \\
\hline$\alpha$-Terpinene & $0.2-2.8$ & Aerial parts, flowers and leaves & {$[85,89,93-95,97]$} \\
\hline$\gamma$-Terpinene & $0.1-1.4$ & Aerial parts, flowers and leaves & {$[85,89,93,94,97]$} \\
\hline Terpinen-4-ol & $<0.01-0.4$ & Aerial parts and leaves & {$[93,95]$} \\
\hline 1-Terpineol & 0.04 & Aerial parts & [93] \\
\hline 4-Terpineol & 0.5 & Flowers and leaves & [97] \\
\hline$\alpha$-Terpineol & $0.1-2.6$ & Aerial parts, flowers and leaves & {$[85,89,94,95,97]$} \\
\hline$\delta$-Terpineol & $0.1-0.9$ & Aerial parts, flowers and leaves & {$[85,89,94,97]$} \\
\hline Terpinolene & $<0.01-0.4$ & Aerial parts, flowers and leaves & {$[85,89,94,95,97]$} \\
\hline$\alpha$-Terpinolene & 0.3 & Aerial parts & [93] \\
\hline
\end{tabular}


Table 3: (Continued)

\begin{tabular}{llll}
\hline Phytochemical composition (\%) & Values & Plant parts & References \\
\hline$\alpha$-Thujene & $<0.01$ & Flowers and leaves & {$[97]$} \\
Valencene & $<0.01-1.9$ & Aerial parts, flowers and leaves & {$[93,97]$} \\
Valerianone & 1.4 & Leaves & {$[95]$} \\
Viridiflorol & $0.7-0.8$ & Aerial parts & {$[85,89,93,94]$} \\
Vulgarol- $\beta$ & 0.7 & Aerial parts & {$[93]$} \\
$\alpha$-Ylangene & $<0.01-0.5$ & Aerial parts, flowers and leaves & {$[85,89,93,94,97]$} \\
\hline
\end{tabular}

studies carried out so far indicate that the species has potential as herbal medicine. Therefore, there is need to validate the documented ethnomedicinal uses of $H$. cymosum through advanced phytochemical and pharmacological studies. There is a lack of in vivo and clinical research on $H$. cymosum and compounds isolated from the species. Further research is required to establish the safety profiles of different $H$. cymosum preparations. Therefore, future studies should address these knowledge gaps through experimental animal studies, randomized clinical trials, and target-organ toxicity studies involving H. cymosum crude extracts and compounds isolated from the species.

\section{ACKNOWLEDGMENTS}

I would like to express my gratitude to the National Research Foundation (NRF), South Africa and Govan Mbeki Research and Development Centre (GMRDC), University of Fort Hare for financial support to conduct this study.

\section{AUTHOR'S CONTRIBUTIONS}

The author declares that this work was done by the author named in this article.

\section{CONFLICTS OF INTEREST}

The author declares that he has no conflict of interest.

\section{REFERENCES}

1. Jeffrey C. Compositae: Introduction with key to tribes. In: Kadereit JW, Jeffrey C, editors. The Families and Genera of Vascular Plants: Eudicots: Asterales. Berlin: Springer-Verlag; 2007. p. 61-86.

2. Amuthan A, Devi V, Shreedhara CS, Rao V, Puri K, Jasphin S. Vernonia cinerea (neichitti keerai) regenerates proximal tubules in cisplatin induced renal damage in mice. Asian J Pharm Clin Res 2019;12:332-5.

3. Maharana L, Sethi MK, Dash RN, Pattnaik S. Evaluation of antidiabetic and antihyperlipidemic effect of Vernonia divergens in streptozotocininduced diabetic rats. Asian J Pharm Clin Res 2019;12:104-10.

4. Jeschke E, Ostermann T, Lüke C, Tabali M, Kröz M, Bockelbrink A, et al. Remedies containing Asteraceae extracts: A prospective observational study of prescribing patterns and adverse drug reactions in German primary care. Drug Saf 2009;32:691-706.

5. Reider N, Komericki P, Hausen BM, Fritsch P, Aberer W. The seamy side of natural medicines: Contact sensitization to arnica (Arnica montana L.) and marigold (Calendula officinalis L.). Contact Dermatitis 2001;45:269-72.

6. Knuesel O, Weber M, Suter A. Arnica montana gel in osteoarthritis of the knee: An open, multicenter clinical trial. Adv Ther 2002;19:209-18.

7. Michler B, Rotar I, Pacurar F, Stoie A. Arnica montana, an endangered species and a traditional medicinal plant: The biodiversity and productivity of its typical grasslands habitats. Grassland Sci Eur 2005; 10:336-40.

8. Oberbaum M, Galoyan N, Lerner-Geva L, Singer SR, Grisaru S, Shashar D, et al. The effect of the homeopathic remedies Arnica montana and Bellis perennis on mild postpartum bleeding - a randomized, double-blind, placebo-controlled study - preliminary results. Complement Ther Med 2005;13:87-90

9. Karow JH, Abt HP, Fröhling M, Ackermann H. Efficacy of Arnica montana D4 for healing of wounds after hallux valgus surgery compared to diclofenac. J Altern Complement Med 2008;14:17-25.

10. Judžentienè A, Bŭdienè J. Analysis of the chemical composition of flower essential oils from Arnica montana of Lithuanian origin. Chemija 2009;20:190-4.
11. Craciunescu O, Constantin D, Gaspar A, Toma L, Utoiu E, Moldovan L, et al. Evaluation of antioxidant and cytoprotective activities of Arnica montana L. and Artemisia absinthium L. Ethanolic extracts. Chem Cent J 2012;6:97.

12. Liao F. Discovery of Artemisinin (Qinghaosu). Molecules 2009; 14:5362-6

13. Miller LH, Su X. Artemisinin: Discovery from the Chinese herbal garden. Cell 2011;146:855-8.

14. Udaykumar P. Discovery of artemisinin: the Chinese wonder drug. Muller J Med Sci Res 2014;5:191-2.

15. Weathers PJ, Towler M, Hassanali A, Lutgen P, Engeu PO. Driedleaf Artemisia annua: A practical malaria therapeutic for developing countries? World J Pharmacol 2014;3:39-55.

16. Chang Z. The discovery of qinghaosu (artemisinin) as an effective antimalaria drug: A unique china story. Sci China Life Sci 2016;59:81-8.

17. Elfawal MA, Towler MJ, Reich NG, Weathers PJ, Rich SM. Dried whole-plant Artemisia аппиа slows evolution of malaria drug resistance and overcomes resistance to artemisinin. Proc Natl Acad Sci U S A 2015;112:821-6.

18. Pulice G, Pelaz S, Matías-Hernández L. Molecular farming in Artemisia аппиа, a promising approach to improve anti-malarial drug production. Front Plant Sci 2016;7:329.

19. Liu CX. Discovery and development of artemisinin and related compounds. Chin Herbal Med 2017;9:101-14.

20. Hamburger M, Adler S, Baumann D, Förg A, Weinreich B. Preparative purification of the major anti-inflammatory triterpenoid esters from marigold (Calendula officinalis). Fitoterapia 2003;74:328-38

21. Chakraborthy GS. Antimicrobial activity of the leaf extracts of Calendula officinalis (Linn.). J Herbal Med Tox 2008;2:65-6.

22. Szakiel A, Ruszkowski D, Grudniak A, Kurek A, Wolska KI, Doligalska M, et al. Antibacterial and antiparasitic activity of oleanolic acid and its glycosides isolated from marigold (Calendula officinalis). Planta Med 2008;74:1709-15.

23. Muley BP, Khadabadi SS, Banarase NB. Phytochemical constituents and pharmacological activities of Calendula officinalis Linn (Asteraceae). Trop J Pharm Res 2009;8:455-65.

24. Fonseca YM, Catini CD, Vicentini FT, Nomizo A, Gerlach RF, Fonseca MJ, et al. Protective effect of Calendula officinalis extract against UVB-induced oxidative stress in skin: Evaluation of reduced glutathione levels and matrix metalloproteinase secretion. J Ethnopharmacol 2010;127:596-601.

25. Arora D, Rani A, Sharma A. A review on phytochemistry and ethnopharmacological aspects of genus Calendula. Pharmacogn Rev 2013;7:179-87.

26. Eddouks M, Lemhadri A, Zeggwagh NA, Michel JB. Potent hypoglycaemic activity of the aqueous extract of Chamaemelum nobile in normal and streptozotocin-induced diabetic rats. Diabetes Res Clin Pract 2005;67:189-95.

27. Zeggwagh NA, Moufid A, Michel JB, Eddouks M. Hypotensive effect of Chamaemelum nobile aqueous extract in spontaneously hypertensive rats. Clin Exp Hypertens 2009;31:440-50.

28. Kazemian H, Ghafourian S, Heidari H, Amiri P, Yamchi JK, Shavalipour A, et al. Antibacterial, anti-swarming and anti-biofilm formation activities of Chamaemelum nobile against Pseudomonas aeruginosa. Rev Soc Bras Med Trop 2015;48:432-6.

29. Al-Snafi AE. Medical importance of Anthemis nobilis (Chamaemelum nobile): A review. Asian J Pharm Sci Technol 2016;6:89-95.

30. Mostafapour Kandelous H, Salimi M, Khori V, Rastkari N, Amanzadeh A, Salimi M, et al. Mitochondrial apoptosis induced by Chamaemelum nobile extract in breast cancer cells. Iran J Pharm Res 2016;15:197-204.

31. Bourrel C, Vilarem G, Perineau F. Chemical analysis, bacteriostatic and fungistatic properties of the essential oil of elecampane (Inula helenium L.). J Essent Oil Res 1993;5:411-7.

32. Konishi T, Shimada Y, Nagao T, Okabe H, Konoshima T. 
Antiproliferative sesquiterpene lactones from the roots of Inula helenium. Biol Pharm Bull 2002;25:1370-2.

33. Konishi T, Kondo S, Uchiyama N. Larvicidal activities of sesquiterpenes from Inula helenium (Compositae) against Aedes albopictus (Diptera: Culicidae) and Paratanytarsus grimmii (Diptera: Chironomidae). Appl Entomol Zool 2008;43:77-81.

34. O'Shea S, Lucey B, Cotter L. In vitro activity of Inula helenium against clinical Staphylococcus aureus strains including MRSA. Br J Biomed Sci 2009;66:186-9.

35. Li Y, Ni ZY, Zhu MC, Dong M, Wang SM, Shi QW, et al. Antitumour activities of sesquiterpene lactones from Inula helenium and Inula japonica. Z Naturforsch C 2012;67:375-80.

36. Spiridon I, Nechita B, Niculaua M, Silion M, Armatu A, Teacă C, et al. Antioxidant and chemical properties of Inula helenium root extracts. Central Eur J Chem 2013;11:1699-709.

37. Wang Y, Tang H, Nicholson JK, Hylands PJ, Sampson J, Whitcombe I, et al. Metabolomic strategy for the classification and quality control of phytomedicine: A case study of chamomile flower (Matricaria recutita L.). Planta Med 2004;70:250-5.

38. McKay DL, Blumberg JB. A review of the bioactivity and potential health benefits of chamomile tea (Matricaria recutita L.). Phytother Res 2006;20:519-30.

39. Amsterdam JD, Li Y, Soeller I, Rockwell K, Mao JJ, Shults J, et al. A randomized, double-blind, placebo-controlled trial of oral Matricaria recutita (chamomile) extract therapy for generalized anxiety disorder. J Clin Psychopharmacol 2009;29:378-82.

40. Amsterdam JD, Shults J, Soeller I, Mao JJ, Rockwell K, Newberg AB, et al. Chamomile (Matricaria recutita) may provide antidepressant activity in anxious, depressed humans: An exploratory study. Altern Ther Health Med 2012;18:44-9.

41. Gupta V, Mittal P, Bansal P, Khokra SL, Kaushik D. Pharmacological potential of Matricaria recutita: A review. Int J Pharm Sci Drug Res 2010;2:12-6.

42. Murti K, Panchal MA, Gajera V, Solanki J. Pharmacological properties of Matricaria recutita: A review. Pharmcognosy 2012;3:348-51.

43. Roby MH, Sarhan MA, Selim KA, Khalel KI. Antioxidant and antimicrobial activities of essential oil and extracts of fennel (Foeniculum vulgare L.) and chamomile (Matricaria chamomilla L.). Ind Crops Prod 2013;44:437-45.

44. van Puyvelde L, De Kimpe N, Costa J, Munyjabo V, Nyirankuliza S, Hakizamungu E, et al. Isolation of flavonoids and a chalcone from Helichrysum odoratissimum and synthesis of helichrysetin. J Nat Prod 1989;52:629-33

45. Dilika NF, Nikolova RV, Jacobs TV. Plants used in the circumcision rites of the Xhosa tribe in South Africa. Acta Hort 1995;426:165-70.

46. Meyer JJ, Afolayan AJ, Taylor MB, Engelbrecht L. Inhibition of herpes simplex virus type 1 by aqueous extracts from shoots of Helichrysum aureonitens (Asteraceae). J Ethnopharmacol 1996;52:41-3.

47. Afolayan AJ, Meyer JJ. The antimicrobial activity of 3,5,7-trihydroxyflavone isolated from the shoots of Helichrysum aureonitens. J Ethnopharmacol 1997;57:177-81.

48. Dilika F, Afolayan AJ, Meyer JJ. Comparative antibacterial activity of two Helichrysum species used in male circumcision in South Africa. S Afr J Bot 1997;63:158-9.

49. Meyer JJ, Afolayan AJ, Taylor MB, Erasmus D. Antiviral activity of galangin isolated from the aerial parts of Helichrysum aureonitens. J Ethnopharmacol 1997;56:165-9.

50. Swanepoel DP. The Medicinal Value of the Southern African Asteraceae. MSc Dissertation. Pretoria: University of Pretoria; 1997.

51. Dilika F, Meyer JJ. Antibacterial activity of Helicltrysum pedunculatum callus cultures. S Afr J Bot 1998;64:312-3.

52. Arnold TH, Prentice CA, Hawker LC, Snyman EE, Tomalin M, Crouch NR, et al. Medicinal and Magical Plants of Southern Africa: An Annotated Checklist. Pretoria: National Botanical Institute; 2002.

53. Drewes SE, Mudau KE, van Vuuren SF, Viljoen AM. Antimicrobial monomeric and dimeric diterpenes from the leaves of Helichrysum tenax var tenax. Phytochemistry 2006;67:716-22.

54. Drewes SE, van Vuuren SF. Antimicrobial acylphloroglucinols and dibenzyloxy flavonoids from flowers of Helichrysum gymnocomum. Phytochemistry 2008;69:1745-9.

55. Aiyegoro OA, Afolayan AJ, Okoh AI. In vitro antibacterial activities of crude extracts of the leaves of Helichrysum longifolium in combination with selected antibiotics. Afr J Pharm Pharmacol 2009;3:293-300

56. Aiyegoro OA, Okoh AI. Preliminary phytochemical screening and in vitro antioxidant activities of the aqueous extract of Helichrysum longifolium DC. BMC Complement Altern Med 2010;10:21.

57. Eroğlu HE, Aksoy A, Hamzaoğlu E, Budak U, Albayrak S. Cytogenetic effects of nine Helichrysum taxa in human lymphocytes culture. Cytotechnology 2009;59:65-72.

58. Drewes SE. Natural products research in South Africa: 1890-2010. S Afr J Sci 2012;108:765.

59. Antunes Viegas D, Palmeira-de-Oliveira A, Salgueiro L, Martinezde-Oliveira J, Palmeira-de-Oliveira R. Helichrysum italicum: From traditional use to scientific data. J Ethnopharmacol 2014;151:54-65.

60. Les F, Venditti A, Cásedas G, Frezza C, Guiso M, Sciubba F, et al. Everlasting flower (Helichrysum stoechas Moench) as a potential source of bioactive molecules with antiproliferative, antioxidant, antidiabetic and neuroprotective properties. Ind Crops Prod 2017;108:295-302.

61. Lourens AC, Viljoen AM, van Heerden FR. South African Helichrysum species: A review of the traditional uses, biological activity and phytochemistry. J Ethnopharmacol 2008;119:630-52.

62. Pljevljakušić D, Bigović D, Janković T, Jelačić S, Šavikin K. Sandy everlasting (Helichrysum arenarium (L.) moench): Botanical, chemical and biological properties. Front Plant Sci 2018;9:1123.

63. Malolo FA, Bissoue Nouga A, Kakam A, Franke K, Ngah L, Flausino $\mathrm{O} \mathrm{Jr}$, et al. Protease-inhibiting, molecular modeling and antimicrobial activities of extracts and constituents from Helichrysum foetidum and Helichrysum mechowianum (compositae). Chem Cent J 2015;9:32

64. van Wyk BE, van Oudtshoorn B, Gericke N. Medicinal Plants of South Africa. Pretoria: Briza Publications; 2013.

65. Zenze K. Helichrysum cymosum (L.) D. Don subsp. Cymosum; 2012. Available from: http://pza.sanbi.org/helichrysum-cymosum-subspcymosum. [Last accessed on 2019 Feb 07].

66. Williams VL, Balkwill K, Witkowski ET. A lexicon of plants traded in the Witwatersrand umuthi shops. Bothalia 2001;31:71-98.

67. Petersen LM, Charman AJ, Moll EJ, Collins RJ, Hockings MT. Bush doctors and wild medicine: The scale of trade in Cape Town's informal economy of wild-harvested medicine and traditional healing. Soc Nat Res 2014;27:315-36.

68. Philander LE, Makunga NP, Esler KJ. The informal trade of medicinal plants by Rastafari bush doctors in the Western Cape of South Africa. Econ Bot 2014;68:303-15.

69. Germishuizen G, Meyer NL. Plants of Southern Africa: An Annotated Checklist. Strelitzia. Vol. 14. Pretoria: National Botanical Institute; 2003

70. Hilliard OM. Asteraceae. In: Leistner OA, editor. Flora of Southern Africa. Part 7 (Inuleae). Vol. 33. Pretoria: Botanical Research Institute; 1983. p. 1-315.

71. Manning JC, Goldblatt P. Plants of the Greater Cape Floristic Region 1: The Core Cape Flora. Strelitzia. Vol. 29. Cape Town: South African National Biodiversity Institute; 2012

72. Sindambiwe JB, Calomme M, Cos P, Totté J, Pieters L, Vlietinck A, et al. Screening of seven selected Rwandan medicinal plants for antimicrobial and antiviral activities. J Ethnopharmacol 1999;65:71-7.

73. Fennell CW, Light ME, Sparg SG, Stafford GI, van Staden J. Assessing African medicinal plants for efficacy and safety: Agricultural and storage practices. J Ethnopharmacol 2004;95:113-21.

74. Stafford GI, Jäger AK, van Staden J. Effect of storage on the chemical composition and biological activity of several popular South African medicinal plants. J Ethnopharmacol 2005;97:107-15.

75. Focho DA, Ndam WT, Fonge BA. Medicinal plants of Aguambu - Bamumbu in the Lebialem highlands, Southwest province of Cameroon. Afr J Pharm Pharmacol 2009;3:1-13.

76. Aston Philander L. An ethnobotany of Western Cape Rasta bush medicine. J Ethnopharmacol 2011;138:578-94

77. Omoruyi BE, Bradley G, Afolayan AJ. Ethnomedicinal survey of medicinal plants used for the management of HIV/AIDS infection among local communities of Nkonkobe Municipality, Eastern Cape, South Africa. J Med Plant Res 2012;6:3603-8.

78. Otang WM, Grierson DS, Ndip RN. Ethnobotanical survey of medicinal plants used in the management of opportunistic fungal infections in HIV/AIDS patients in the Amathole district of the Eastern Cape province, South Africa. J Med Plant Res 2012;6:2071-80.

79. Heyman HM. Identification of anti-HIV Compounds in Helichrysum Species (Asteraceae) by Means of NMR-Based Metabolomic Guided Fractionation. PhD Thesis. Pretoria: University of Pretoria; 2013.

80. Masafu MM, Mbajiorgu CA, Nemadodzi LE, Kabine ES. A study of natural habitats and uses of medicinal plants in Thulamela and JS Moroka Municipalities, South Africa. Indian J Trad Knowl 2016; $15: 363-9$

81. Hulley IM, van Wyk BE. Quantitative medicinal ethnobotany of Kannaland (Western Little Karoo, South Africa): Non-homogeneity amongst villages. S Afr J Bot 2018;122:225-65. 
82. Bhat RB, Jacobs TV. Traditional herbal medicine in Transkei. J Ethnopharmacol 1995;48:7-12.

83. Tyiso S, Bhat RB. Medicinal plants used for child welfare in the Transkei region of the Eastern Cape (South Africa). J Appl Bot 1998;72:92-8

84. Dlisani PB, Bhat RB. Traditional health practices in Transkei with special emphasis on maternal and child health. Pharm Biol 1999;37:32-6.

85. Reddy D. The Phytochemistry and Antimicrobial Activity of Selected Indigenous Helichrysum species. MSc Dissertation, Johannesburg: University of the Witwatersrand; 2007.

86. Lourens AC. Structural and Synthetic Studies of Sesquiterpenoids and Flavonoids Isolated from Helichrysum Species. PhD Thesis. Pietermaritzburg: University of KwaZulu-Natal; 2008.

87. Bhat RB. Plants of Xhosa people in the Transkei region of Eastern Cape (South Africa) with major pharmacological and therapeutic properties. J Med Plant Res 2013;7:1474-80.

88. Kakudidi EK. Cultural and social uses of plants from and around Kibale National Park, Western Uganda. Afr J Ecol 2004;42:114-8

89. van Vuuren SF, Viljoen AM, van Zyl RL, van Heerden FR, Hüsnü K, Başer $\mathrm{C}$. The antimicrobial and toxicity profiles of helihumulone, leaf essential oil and extracts of Helichrysum cymosum (L.) D. Don subsp. cymosum. S Afr J Bot 2006;72:287-90.

90. Street RA, Kulkarni MG, Stirk WA, Southway C, van Staden J. Variation in heavy metals and microelements in South African medicinal plants obtained from street markets. Food Addit Contam Part A Chem Anal Control Expo Risk Assess 2008;25:953-60.

91. Bohlmann F, Ziessche J, Mahata PK. Neue chalkon-derivate und humulon-ähnliche verbindungen aus Helichrysum-artn. Phytochem 1979; 18:1033-6

92. Jakupovic J, Zdero C, Grenz M, Tsichritzis F, Lehmann L,
Hashemi-Nejad SM, et al. Twenty-one acylphloroglucinol and further constituents from South African Helichrysum species. Phytochem 1989;28:1119-31.

93. Bougatsos C, Ngassapa O, Runyoro DK, Chinou IB. Chemical composition and in vitro antimicrobial activity of the essential oils of two Helichrysum species from Tanzania. Z Naturforsch C 2004;59:368-72

94. van Vuuren SF. The Antimicrobial Activity and Essential Oil Composition of Medicinal Aromatic Plants used in African Traditional Healing. PhD Thesis. Johannesburg: University of the Witwatersrand; 2007.

95. François T, Lambert SM, Michel JD, Gaby NM, Fabrice FB, Zaché N, et al. Composition, radical scavenging and antifungal activities of essential oils from 3 Helichrysum species growing in Cameroon against Penicillium oxalicuma yam rot fungi. Afr J Agric Res 2010;4:121-7.

96. Ras AM. Essential oil yield and composition of three Helichrysum species occurring in the Eastern Cape province of South Africa. S Afr J Bot 2013;86:181

97. Giovanelli S, De Leo M, Cervelli C, Ruffoni B, Ciccarelli D, Pistelli L, et al. Essential oil composition and volatile profile of seven Helichrysum species grown in Italy. Chem Biodivers 2018;15:e1700545.

98. Runyoro DK, Ngassapa O, Kachali L, Obare V, Lyamuya EF. Biological activities of essential oils from plants growing in Tanzania. East Central Afr J Pharmaceut Sci 2010;13:85-91.

99. Heyman HM. Metabolomic Comparison of Selected Helichrysum Species to Predict their Antiviral Properties. MSc Dissertation. Pretoria: University of Pretoria; 2009.

100. Heyman HM, Senejoux F, Seibert I, Klimkait T, Maharaj VJ, Meyer JJ, et al. Identification of anti-HIV active dicaffeoylquinic- and tricaffeoylquinic acids in Helichrysum populifolium by NMR-based metabolomic guided fractionation. Fitoterapia 2015;103:155-64. 